Economics for Lawyers 
This page intentionally left blank 


\section{ECONOMICS FOR LAWYERS}

Richard A. Ippolito

Princeton University Press

Princeton and Oxford 
Copyright ( 2005 by Princeton University Press Published by Princeton University Press, 41 William Street, Princeton, New Jersey 08540 In the United Kingdom: Princeton University Press, 3 Market Place, Woodstock, Oxforshire OX20 1SY All Rights Reserved

Library of Congress Cataloging-in-Publication Data Ippolito, Richard A.

Economics for lawyers / Richard A. Ippolito.

p. cm.

Includes bibliographical references and index.

ISBN 0-691-12177-X (cl : alk. paper)

1. Law and economics. 2. Economics. 3. Law-

Economic aspects-United States. I. Title.

K487. E3I67 2005

$330^{\prime} .024^{\prime} 34-\mathrm{dc} 22$

British Library Cataloging-in-Publication Data is available This book has been composed in 10/12 Sabon Printed on acid-free paper. $\infty$ pup.princeton.edu Printed in the United States of America 10987654321 